\title{
A Framework For The Income Tax Deductibility Of Intellectual Property Expenditure Incurred By South African Taxpayers \\ Rudi Oosthuizen, University of Pretoria, South Africa
}

\begin{abstract}
Taxpayers who use intellectual property (such as patents and trademarks) in their trade in the production of income may obtain the right of such use in a number of different ways. The nature of the transaction granting the taxpayer the use of intellectual property items determines the tax treatment thereof. Taxpayers may be able to claim deductions for the cost of using these items in terms of specific income tax sections or the general deduction formula as outlined by the Income Tax Act 58 of 1962. There are also a number of other sections in the Act which may affect the timing and extent of the deductions allowed.
\end{abstract}

This article investigates the various income tax deductions which may be available to taxpayers in South Africa who make payments in respect of intellectual property. It considers the effect of important recent case law and changes to tax legislation on the timing and extent of these deductions and suggests a framework which can be applied to assist the taxpayer in understanding the structure of such deductions.

Keywords: Income Tax Deductibility; South Africa; Intellectual Property

\section{INTRODUCTION}

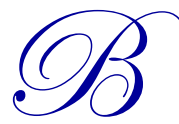

usinesses often use intellectual property, regardless of the products they make or the services they provide. As a result of rapid changes and advancements in technology, these intangible assets are becoming more valuable in relation to businesses' physical assets. Intellectual property items include brands, patents, trademarks, designs, and copyright. Taxpayers often incur considerable expenses in acquiring these intellectual property rights which award the taxpayer the opportunity to use these rights in a trade to produce income. The taxpayer could develop these rights or purchase them from another person. A taxpayer may also merely use the intellectual property rights owned by someone else in exchange for the payment of consideration; for example, in the form of royalties or premiums. As the income generated by these rights could be taxed in terms of the Income Tax Act 58 of 1962 (referred to as the "Act"), the question is whether the expenses incurred in acquiring the rights will be deductible. In this article, all references to sections are references to sections of the Act.

Income tax deductions available to South African taxpayers are regulated mainly by sections 11 to 19 and 23 (De Koker, 2010). Some of these sections allow for the deduction of specific items of expenditure or loss for tax purposes. If there is no specific deduction provided for in the Act for a certain item of expenditure, a deduction may be sought in terms of the "general deduction formula" contained in section 11(a).

During the past ten years, several court cases have dealt with the deductibility of intellectual property payments for income tax purposes, whether in terms of section 11(a) or other specific sections. Of particular concern is the decision reached in a Cape Tax Court case, ITC 1798 (68 SATC 9), in which it was held that royalty payments made by a taxpayer in terms of a trademark license agreement were of a capital nature and therefore not deductible 
in terms of the general deduction formula. Until the decision was reached in this case, royalty payments have generally been regarded as non-capital expenditure and consequently allowed as deductions.

However, in the subsequent Supreme Court of Appeal decision (BP Southern Africa (Pty) Ltd v. The Commissioner for SARS, 2007, SCA 7 (RSA) (69 SATC 79)), the court overturned the decision of the Cape Tax Court and held that the purpose of expenditure is important and often decisive in determining whether the expenditure is capital or non-capital in nature. The court held that the royalty expenses were not of a capital nature and therefore deductible. It was made clear that royalty payments will not automatically be of a non-capital nature.

Although the decision of the Supreme Court of Appeals provided a certain amount of relief to taxpayers claiming royalty payments as deductions, it is still necessary to determine which factors need to be taken into account in order to provide certainty to taxpayers as to the tax deductibility of such payments.

During this period there have also been various changes to certain sections of the Act that deal with intellectual property. All of these changes must be taken into account when drafting any contract providing for the payment of royalties or similar amounts. Failure to fully understand the effect of these recent developments may result in unintended and potentially severe tax losses.

This article aims to identify the factors which need to be considered by a taxpayer when determining whether such payments will qualify for income tax deductions. The article further aims to construct a framework to be applied in determining the deductibility of such expenditure. To achieve this, a study was made of all the specific sections of the Act that apply to intellectual property deductions. An analysis was also made of the general deduction formula, with specific focus on the capital or non-capital nature of intellectual property payments. The research therefore involved an analysis of the relevant sections of the Act, as well as the decisions and comments of the courts in recent case law dealing with both specific sections as well as the general deduction formula.

In the next section, the relevant literature is reviewed and the article concludes with a summary of the findings.

\section{OVERVIEW OF THE PROCESS OF DETERMINING DEDUCTIBILITY}

The South African taxpayer needs to consider whether the Act provides for a specific deduction for the type of intellectual property expenditure incurred. The amount and timing of the various specific deductions depend on whether the taxpayer has spent amounts on developing or acquiring the intellectual property items or whether payments were merely made to someone else for the use of these items. In terms of section 82, the onus of proof will be on the taxpayer to prove that a deduction must be allowed. The research on which this article is based identified a structured approach to determine the deductibility of these payments. A summary of the process to determine whether certain intellectual property expenditure is deductible is provided in Figure 1. The rest of the article will provide an analysis of the various components of this structure. 


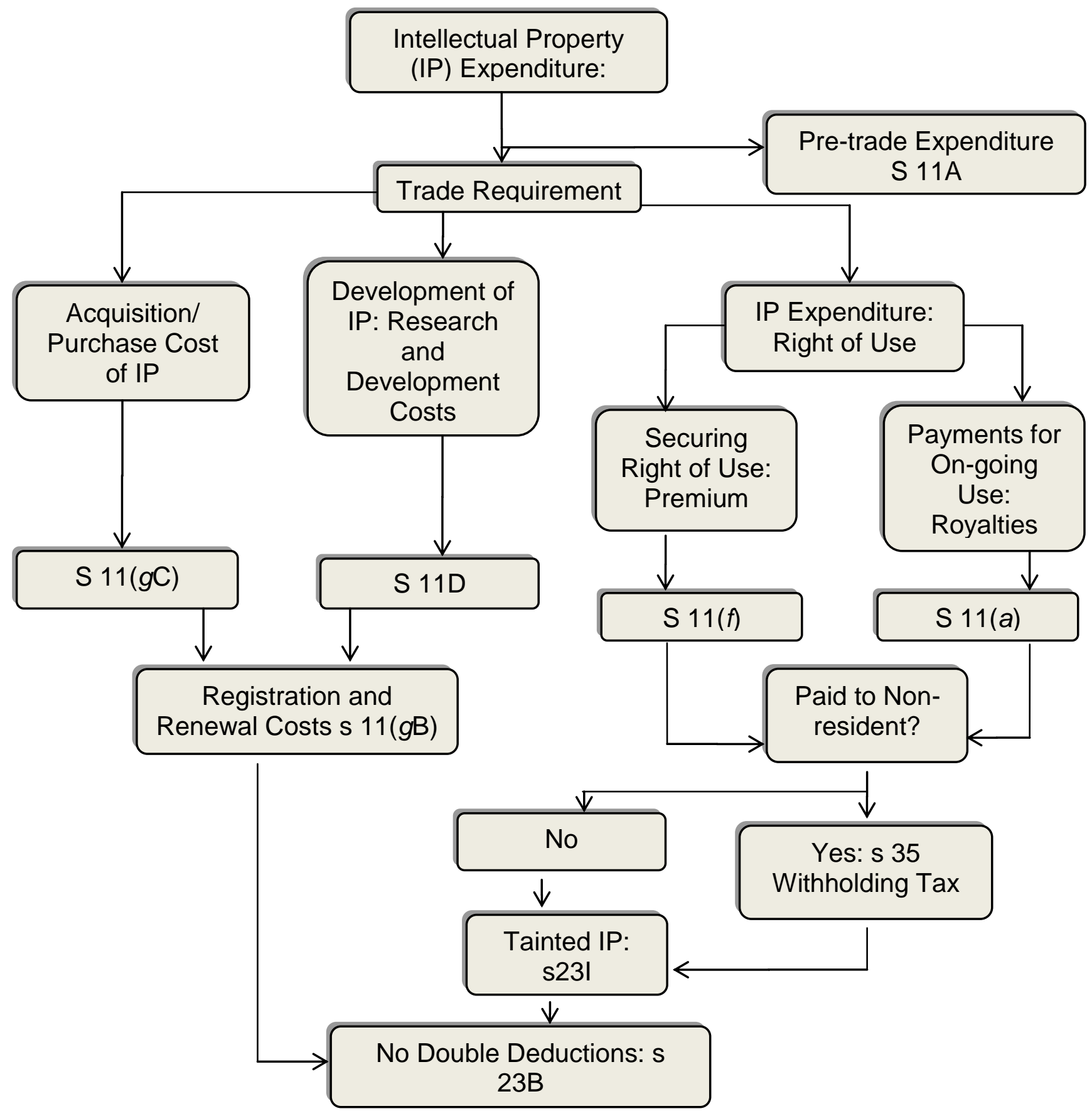

Figure 1: Overview of the Process of Determining Deductibility

\section{THE TRADE REQUIREMENT}

The deductions discussed in this article are available in terms of section 11 (other sections may have an impact on the amount and timing of such deductions; e.g., sections 23B and 23I). Before a taxpayer may claim a deduction in terms of section 11, he or she must be carrying on a trade and must be earning income from that trade. This requirement is stated in the introduction to section 11 and is therefore applicable to both the general deduction formula and specific deductions in terms of the provisions of section 11. 
The term "trade" is defined in section 1 and includes the use of or the granting of permission to use any patent, design, trademark, copyright, or property of a similar nature. Therefore, this will include the use of most types of intellectual property by the taxpayer in exchange for the payment of royalties to the creator of such intellectual property.

In some cases, the taxpayer may incur expenses before commencing trade. In terms of section 11, these expenses would not be deductible as there is no trade being carried on. Section 11A allows the deduction of expenses (including all the intellectual property expenditure discussed in this article) incurred by a taxpayer prior to commencement of trade once the taxpayer starts trading (providing all the section's requirements are met).

\section{ACQUISITION/PURCHASE COST OF INTELLECTUAL PROPERTY}

Section $11(\mathrm{gC})$ applies to expenditure incurred to acquire/purchase certain intellectual property items (inventions or patents, designs, copyright, or other property of a similar nature, as well as knowledge essential for the use of such items or the right to have such knowledge imparted) on or after 1 January 2004. Expenditure incurred prior to 1 January 2004 had to be deducted in terms of section $11(\mathrm{gA})$. Section $11(\mathrm{gC})$ is similar to the part of section $11(\mathrm{gA})$ that dealt with purchased intellectual property. It applies to the same types of property (except that section 11 $(\mathrm{gA})$ allowed for deductions on the cost of trademarks up to 29 October 1999, while section $11(\mathrm{gC})$ completely disallows the deduction of expenses incurred for the acquisition of trademarks) and provides for the same write-off periods offered by section $11(\mathrm{gA})$.

It is necessary to investigate the agreement in respect of the intellectual property thoroughly in order to determine whether the taxpayer is acquiring the property itself or merely paying a premium for the right of use.

If expenditure is incurred in the acquisition of qualifying intellectual property items which are used by the taxpayer in the production of income, the section allows for the deduction of the full amount of the expense (if it is under R5000) or an annual allowance of 5\% of cost (if it exceeds R5000). If the item purchased is a design and the amount exceeds R5000, the annual allowance is $10 \%$.

In ITC 1838 (72 SATC 6), it was argued by the Commissioner that the part of the purchase price of a radio station that related to the station's trademarks should not be deductible in terms of section $11(\mathrm{gA})$ due to the fact that it was artificially inflated. The court held that, due to the fact that the section allowed for the deduction of "expenditure actually incurred", the market value of the trade marks was irrelevant. The taxpayer was allowed a deduction in terms of section $11(\mathrm{gA})$.

Although no deduction is currently allowed for the purchase of trademarks in terms of section $11(\mathrm{gC})$ (which has replaced section 11( $\mathrm{gA})$ ), the above-mentioned court decision could have an impact when other types of intellectual property are acquired as part of the purchase of a business. According to Keyser and Mostert (2009), it is important for a taxpayer purchasing an entire business as a going concern to determine the exact nature of all the assets he or she is acquiring. If any of those assets are of the type referred to in section $11(\mathrm{gC})$, the purchaser may be entitled to a specific deduction. It is suggested that the taxpayer obtain expert advice when acquiring trademarks from a seller. The taxpayer should establish whether copyright subsists in those trademarks and should allocate the appropriate portion of the purchase price to such copyright.

\section{"Property of a Similar Nature"}

Both section $11(\mathrm{gA})$ and section $11(\mathrm{gC})$ refer to 'property of a similar nature'. The meaning of this term has been the subject of a number of recent court cases.

In ITC 1726 (64 SATC 236), a taxpayer wantęd to deduct license fees paid in respect of the acquisition of cellular license fees as well as for the renewal of such fees. The taxpayer was not allowed a deduction in terms of section 11(a) but contended that a deduction should be allowed in terms of section 11( $\mathrm{gA}$ ) since the license could be regarded as 'property of a similar nature' (as stated above, section $11(\mathrm{gC})$, as is currently applicable, but both sections allow for the deduction in respect of 'property of a similar nature'). The court held that the ordinary 
grammatical interpretation of the phrase 'property of a similar nature' found in section $11(\mathrm{gA})$ refers to the acquisition of intellectual property. This means that the phrase applies only to property which came into existence by exercising intellectual powers. It was held that the cellular license could not be regarded as "property of a similar nature" and a deduction for the fee was not allowed in terms of section $11(\mathrm{gA})$. This view was confirmed in C:SARS v SA Silicone Products (Pty) Ltd, 2004 (66 SATC 131 (SCA)).

If a taxpayer acquires a right in respect of property which is not specifically listed in section $11(\mathrm{gC})$, the taxpayer will only be entitled to a deduction if he or she can show that the property is the result of the exercise of intellectual powers.

\section{DEVELOPMENT OF INTELLECTUAL PROPERTY: RESEARCH AND DEVELOPMENT COSTS}

A taxpayer may also incur expenditure in creating or devising his or her own intellectual property instead of using or purchasing property which belongs to someone else. The taxpayer may seek a deduction for such expenses in terms of section 11D. This section was rewritten in 2011 and, in its current format, applies to expenditure incurred on or after 1 April 2012 but before 1 April 2022.

Section 11D allows a taxpayer a deduction for expenditure actually incurred directly and solely for research and development. Research and development is defined in section $11 \mathrm{D}(1)$ as 'systematic investigative or systematic experimental activities of which the results are uncertain'. These activities could be undertaken for the purposes of:

- $\quad$ the discovery (being something that already existed and is brought to the discoverer's awareness) of nonobvious scientific or technological knowledge or

- the creation, developing, or improving of any invention, design, or computer program, as well as knowledge essential to its use

Section 11D requires that the expenditure must be incurred in South Africa. It does not require that the intellectual property must be registered in South Africa. According to SARS (2007), if the taxpayer incurs the expenditure in South Africa but the intellectual property is registered outside of the country, the taxpayer may still qualify for the section 11D deductions.

Section 11D(2) requires that the expenditure must be incurred by the taxpayer in the production of his or her income in the carrying on of a trade. SARS (2009) states that, if a taxpayer incurs research and development expenditure before commencing trade, he or she may qualify to deduct those expenses in terms of section 11A during the year in which he or she commences to trade.

Section 11D(8) states that the deductions of section 11D are not available for certain expenditures. This includes expenditure in respect of, amongst others, market research, administration, social science research, trademarks, goodwill, or any expenditure already deductible in terms of section $11(\mathrm{~g} B)$ or section $11(\mathrm{~g} C)$.

\section{Deduction for Operational (Non-capital) Expenditure}

If the above-mentioned requirements are met, the taxpayer is allowed a deduction of $100 \%$ of expenditure actually incurred (section $11 \mathrm{D}(2)$ ). In addition to the $100 \%$ deduction, the taxpayer could qualify for a further deduction of 50\% of the research and development expenditure incurred (sections 11D(3) and 11D(4)). This additional $50 \%$ is available in the following two situations:

- if the taxpayer is a company and the expenditure is incurred in respect of research and development (as approved in terms of the requirements of section 11D(9)) undertaken by the taxpayer or

- $\quad$ if the taxpayer incurs expenditure to fund the expenditure of another person carrying on research and development (as approved in terms of the requirements of section 11D(9)) on behalf of the taxpayer. This is only applicable if the other person carrying on the research and development is an institution, board or body that is exempt from normal tax under section 10(1)(cA), if it is the Council for Scientific and Industrial Research (CSIR), or if it is a company forming part of the same group of companies that has not claimed the additional $50 \%$ itself. 
If a government grant is received by a taxpayer to fund research and development expenditure, the amount of the government grant must be deducted from the actual research and development expenditure before the additional $50 \%$ is calculated (section $11 \mathrm{D}(7)$ ).

\section{Deduction for Capital Expenditure}

If a taxpayer incurs expenditure on or after 1 April 2012 but before 1 April 2022 to acquire new or unused research and development machinery or plant, the taxpayer qualifies for a deduction of $40 \%$ of the cost thereof in the first year of its use (not apportioned for a part of a year) and $20 \%$ in each of the subsequent three years in terms of section 12C. If the expenditure is incurred to acquire a building owned by the taxpayer and which is used for research and development, the deduction is 5\% of the cost thereof (not apportioned for a part of a year) over a period of twenty years in terms of section 13(1).

\section{REGISTRATION/RENEWAL COST OF DEVELOPED INTELLECTUAL PROPERTY: SECTION 11(GB)}

In order to enjoy statutory protection in respect of their intellectual property rights, South Africans have to register the intellectual property with the Companies and Intellectual Property Commission (CIPC) before 1 May 2011, the Companies and Intellectual Property Registration Office (CIPRO) of the Department of Trade and Industry of South Africa. Registration and renewal fees may be charged when such property rights are registered.

If the taxpayer incurs such expenditure in respect of obtaining or extending the registration of a patent, design, or trademark, the expenditure may be deducted by the taxpayer in the year of assessment in which it was incurred, provided the patent, design, or trademark is used by the taxpayer in the production of his or her income (section $11(\mathrm{gB}))$.

\section{INTELLECTUAL PROPERTY EXPENDITURE: RIGHT OF USE}

A taxpayer may also decide not to acquire or develop his or her own intellectual property but to make certain payments to other taxpayers for the right to use intellectual property. In such case, the taxpayer does not become the holder of the intellectual property.

\section{Securing Right of Use: Premium (Section 11(f))}

Payments made in respect of premiums will generally not qualify for deduction in terms of the general deduction formula since they are usually regarded as of a capital nature. Section 11(f) allows for the deduction of an allowance in respect of any premium or consideration in the nature of a premium paid by a taxpayer for the right of use of any patent, design, trademark, copyright, or any other property that is of a similar nature if such item is used for the production of income or income is derived from it (section 11(f)(iii)).

It has been held in CIR $v$ Butcher Bros (Pty) Ltd,1945 AD (13 SATC 21) that 'premium' means consideration in the nature of rent passing from a lessee to a lessor over and above or in lieu of the rental payments.

Having regard to the circumstances of the taxpayer, it may be apparent that the payment(s) made by the taxpayer for the use of intellectual property constitute(s) the securing of a right to use the relevant intellectual property items. These payments are in other words not seen as amounts expended for the continued use of the assets, but rather as amounts for the acquisition of an income-producing structure. Under these circumstances, the payments could be classified as a 'premium' paid by the taxpayer for the right to use the intellectual property, which may qualify for deduction in terms of section 11(f) of the Act.

The amount of the deduction which may be claimed in any year of assessment is the amount of the premium divided by the number of years during which the taxpayer will have the right to use such asset. The number of years over which the deduction of the amount is spread is limited to 25 years. If the taxpayer pays the premium for the use of the asset for an indefinite period or if the taxpayer has the right to renew the agreement after its expiry, the period over which the deduction is to be spread is the period which the Commissioner deems to be the probable duration of such use (still limited to 25 years). 
Section 11(f) also allows for a deduction in a situation where a taxpayer pays a premium or consideration in the nature of a premium for 'the imparting of, or the undertaking to impart, any knowledge directly or indirectly connected with the use of such ... patent, design, trademark, copyright, or other property as aforesaid' (section $11(f)(\mathrm{iv}))$. The allowance, which may be deducted for any year of assessment for this type of premium, is the amount of the premium which the Commissioner may allow. It is provided that the Commissioner will take into account the period during which the taxpayer will have the right of use of the underlying intellectual property, as well as all other relevant circumstances. Therefore, while the deduction for the premium for the right of use of the intellectual property is automatic, this deduction is determined by the discretion of the Commissioner.

This implies that when a taxpayer pays a premium in terms of an agreement for the use of intellectual property items, it is important to determine which part of the premium relates to the right to use the property and which part relates to securing the right to the knowledge in respect of such property (for example, the right to obtain support from the holder of the right during the duration of the agreement).

The section 11(f) allowance may not be claimed 'in relation to any such premium or consideration paid by the taxpayer who does not constitute income of the person to whom it is paid...' An example of this situation is where a taxpayer pays such a premium to a non-resident taxpayer who may (in terms of the definition of "gross income" in section 1 of the Act) not have included it in his or her 'income' if it was not from a source within or deemed to be within South Africa. Another example is where a taxpayer pays such a premium to a tax-exempt body (for example, a Public Benefit Organisation).

\section{Payments for On-going Use: Royalties (section 11(a))}

If a taxpayer makes an intellectual property payment which does not qualify for a specific deduction, the taxpayer could seek a deduction in terms of the general deduction formula. Section 11(a) of the Act allows as a deduction from the taxable income of a person carrying on a trade, any expenditure and losses actually incurred during the year of assessment in the production of income, provided such expenditure and losses are not of a capital nature.

The main problem when dealing with the deductibility of royalty and similar payments is whether such payments represent expenditure of a capital or non-capital nature. There have been numerous court cases dealing with this issue. This article reports on an investigation of some of the court decisions which have dealt with the capital or non-capital nature of expenditure, in general, as well as decisions which have considered the issue in relation to intellectual property specifically.

\section{Court Cases Which Have Dealt With the Capital Issue In General}

According to De Koker (2010), it is often difficult to distinguish between capital and non-capital or "revenue" expenditure. As the meaning of "capital" is not defined in the Act, it is necessary to take into account the numerous court cases that have dealt with this issue. These court cases have laid down a number of useful tests that can be applied when ascertaining whether expenditure is of a capital or revenue nature.

A very important test, and one which is especially applicable when ascertaining the nature of intellectual property payments, is the one laid down in New State Areas Ltd v CIR, 1946AD 610 (14 SATC 155) where it was held that it should be established whether the expenditure can be regarded as part of the cost of performing the income-earning operations or as part of the cost of establishing, improving, or adding to the income-earning structure.

Watermeyer CJ stated, in this case, that "the true nature of each transaction must be inquired into in order to determine whether the expenditure attached to it is capital or revenue expenditure". The true nature of each expense is a matter of fact and, in this regard, it is important to look at the purpose of the expense. If an expense is incurred for the purpose of acquiring a capital asset for the business, it is capital expenditure. This will be the case, even if the expense is paid in annual instalments. On the other hand, if the expense can be regarded as part of the cost incidental to the performance of the income-producing operations, it is a non-capital expense, even if it is paid in a lump sum. 
In Vallambrosa Rubber Co v Farmer, 1910(5 TC 529), the Scottish Court of Session held that it has to be determined whether the expenditure was a "once-and-for-all" expenditure or whether it was likely to recur. According to this test, capital expenditure is something that is going to be spent once and for all and income expenditure is going to recur regularly. According to De Koker (2010), this test is not infallible because a "onceand-for-all" payment may yet be revenue expenditure and a recurring expenditure may well constitute capital expenditure.

In the English case British Insulated and Helsby Cables Ltd v Atherton, 1926 AC 205 All ER 623(10 TC 155), the "enduring benefit" test was laid down. In terms of this test, if an expense secures an asset of a sufficiently enduring nature for the taxpayer, it will represent an expenditure of a capital nature. It has to be determined what time period is to be considered as sufficiently "enduring". The answer to this question depends on the facts of the case.

The taxpayer has to be careful when applying the above tests to the payment of royalties as the tests laid down by the courts merely serve as general guidelines; no one test can be applied on its own to reach a conclusion. Taking into account the particular facts and circumstances of each case, all of these factors have to be considered together.

\section{Court Cases Which Have Dealt With Intellectual Property Specifically}

In addition to the factors outlined above, this article also considers some important guidelines established by the courts in determining the capital or non-capital nature of certain intellectual property expenditure.

ITC 1224 (37 SATC 30)

A taxpayer had incurred expenditure in acquiring licences for new branches (retail shops) and claimed a deduction in terms of section 11(a). The court held that the licences obtained by the taxpayer created an asset of an enduring nature and that the corresponding expenditure was of a capital nature. This conclusion was not affected by the fact that the taxpayer had to renew the licences annually. The subsequent renewal expenditure may be deductible in terms of section 11(a) (if all the requirements are met), but the initial fees paid for acquiring the licences are of a capital nature. Thus, if a taxpayer has entered into a licensing agreement, it is important to determine the nature of the benefits obtained by the payment of the relevant fees.

Commissioner, SARS v Kajadas Cosmetics (Pty) Ltd, 2002 (4) SA 709 (T) (64 SATC 200)

The taxpayer had acquired the exclusive right to sell a product in South Africa. The initial period of the agreement was five years after which it would automatically be renewed unless it were to be terminated in accordance with the provisions of the agreement. The taxpayer would pay an annual fee to the licensor for the distribution rights. The judge stated:

[w] hat is an outgoing of capital and what is an outgoing of revenue depends on what the expenditure is calculated to effect from a practical and business point of view rather than upon the juristic classification of the legal rights.

Therefore, even though the amounts paid by the taxpayer were payable recurrently, the court held that the right to distribute the product which was paid for was an income-earning machine. The expenditure was therefore held to be of a capital nature.

The conclusion from this view is that the mere recurrent nature of a licence fee will not necessarily classify the expenditure as of a non-capital nature. It is important to take into account exactly what those payments secure for the taxpayer from a business point of view. Evidently, the facts and circumstances will differ from one case to the next. 
ITC 1798 (68 SATC 9)

In a Cape Tax Court case, ITC 1798 (68 SATC 9), it was held that royalty payments made by a taxpayer in terms of a trademark license agreement were of a capital nature and therefore not deductible in terms of the general deduction formula. Until the decision was reached in this case, royalty payments have generally been regarded as of a non-capital nature and consequently allowed as deductions as they were seen as expenses that form part of the dayto-day running expenses of a taxpayer's business. Erasmus (2007) states that this is likened to the rental paid by the taxpayer for business premises.

The royalty amounts in this case were based on the profit actually generated, which could be attributed to the licensed marks. If the royalty agreement would ever be terminated, the taxpayer would no longer be entitled to use its trade name which was linked to the trademark. The taxpayer was only allowed to use the licensed marks in South Africa.

In arguing that the royalty payments were of a non-capital nature, the taxpayer emphasised that ownership of the marks was vested and remained in the British parent company and that the taxpayer obtained no enduring benefit as the contract was terminable on six months' notice. The taxpayer also noted that the payment of the royalty was repetitive and occurred annually, which made it similar, in nature, to rental, which is deductible.

SARS, on the other hand, cited the following reasons for their view that the royalty payments were of a capital nature:

- $\quad$ the payments were made in respect of the right to operate under the name and style of the taxpayer, which enhanced and maintained the brand of the taxpayer

- $\quad$ the purpose of the expenditure incurred by the taxpayer was to enable the taxpayer to retain its South African market share, name, and reputation

- $\quad$ the taxpayer was unable to trade without the use of the marks, which created an opportunity to earn income;

- $\quad$ royalty payments are no different from payments made under franchise agreements, which are capital in nature

- the payment of the royalty created an advantage of an enduring benefit for the taxpayer

It was argued by SARS that the Court should enquire into the purpose of the expenditure. They referred to the case of CIR v Genn \& Co (Pty) Ltd, 1955 (3) SA 293 (A) (20 SATC 13) where the Court held that

[i]n deciding how the expenditure should properly be regarded, the Court clearly has to assess the closeness of the connection between the expenditure and the income-earning operations, having regard both to the purpose of the expenditure and to what it actually affects.

The court further held that the nature and effect of the property paid for differed from mere rental in two significant respects:

- $\quad$ without these marks and indicia, the taxpayer would not be able to be in a position to trade. It wanted to remain in the market as an international brand, particularly one that had a well-established market in South Africa, in order to retain existing customers and attract new ones, and thus maintain and grow its market share

- this situation was different from the landlord-tenant scenario since it cannot necessarily be said that the premises rented by a tenant are indispensable for the taxpayer's business. A trademark must be distinctive and capable of being distinguished from all other marks. A fixed asset on its own does not give identity to the occupant and also does not carry with it the reputation association with a product as is the case with a trademark. Also, if a lease is terminated, the tenant would be able to move to other premises without its structure and goodwill being affected.

Therefore, it was held that the trademark gave the taxpayer structure and goodwill without which it would be unable to continue its operations in the form and style it used to do. 
A reference was also made to the Australian case of Hallstrom Pty Ltd v FCT, (1946) 3 AITR 436 (72 CLR 634) which held that:

[w] hat is an outgoing of capital and what is an outgoing of revenue depends on what the expenditure is calculated to effect from a practical and business point of view, rather than upon the juristic classification of the legal rights, if any, secured, employed, or exhausted in the process.

The Judge applied this test to the facts and stated that the taxpayer's purpose in incurring the expenditure was to enable it to:

- $\quad$ continue to differentiate the products it manufactured and marketed from the products marketed by its competitors under the other brand names

- $\quad$ avoid the very significant costs of re-branding itself and its products

- take advantage of the reputation which the taxpayer had established over the years with the use of the licensed mark and licensed marketing indicia in South Africa

- $\quad$ build on the reputation which the taxpayer had established over the years with the use of the licensed mark and licensed marketing indicia in South Afric

- $\quad$ attract customers, thereby maintaining and enhancing the taxpayer's profit and maintaining and increasing the taxpayer's market share

It was further held in CIR v Genn \& Co (Pty) Ltd, 1955 (3) SA 293 (A) (20 SATC 13) that the fact that a payment is labelled as a royalty does not detract from the fact that it may be capital in nature. A taxpayer can therefore not structure payment for income-producing structure to contain repayments in the form of 'royalties' and claim that it should be deductible on that basis alone.

The court also decided that the manner in which the royalty payment was calculated; namely, as a percentage of volume sold, does not automatically mean that the payment is of a non-capital nature. In the court's opinion, this was merely a basis of costing the expense of the asset. Furthermore, the recurring nature of the expenditure did not detract from the expenditure's capital nature.

It was therefore held that the payments in issue were, in substance, a purchase price for a business that had a substantial market share and was of a capital nature.

Du Plessis (2006) states that although tax court cases do not constitute binding precedent and that the decision of the court was overturned in the subsequent Supreme Court of Appeals case (discussed below), such cases are relevant because they have persuasive power. The comments made by the court in this case give an indication of the matters which may be raised should a court be deciding on the capital or non-capital nature of royalty payments.

BP Southern Africa (Pty) Ltd v. The Commissioner for SARS, 2007 SCA 7 (RSA) (69 SATC 79)

In this case, the court held that the purpose of expenditure is important and often decisive in determining whether the expenditure is capital or non-capital in nature. The true nature of each transaction must be examined in order to determine the actual purpose thereof. In deciding the true nature of a transaction, each case must be decided on its own facts and circumstances (CIR v African Oxygen Ltd, 1963 (1) SA 681(A) (25 SATC 67)).

The court took into account the following factors:

- the taxpayer obtained a non-exclusive and non-assignable authorisation to use the licensed marketing indicia

- $\quad$ the licensor remained the sole rightful owner of the licensed marks and licensed marketing indicia and all rights and goodwill attaching to or arising out of the use thereof by the taxpayer, accrued to the benefit of the licensor 
- $\quad$ upon termination of the agreement, the taxpayer would no longer be entitled to use the said licensed marks and indicia

- the brief initial duration of the agreement between the taxpayer and the licensor, and the relatively short period required for termination after that initial period, should be taken into account

- the agreement between the parties made it clear that the royalties were paid for the use of the licensed marks and marketing indicia; ownership of the intellectual property therefore remained with the licensor

- $\quad$ the recurrent nature of the payments is a strong indicator that the expenditure is of a non-capital nature

- $\quad$ the expenditure, in this case, neither created nor preserved any capital asset in the hands of the taxpayer

In the court's opinion, the royalty expenditure was more closely connected to the taxpayer's income-earning operations and therefore of a non-capital nature. The expenditure was therefore held (at 84 ) to be deductible in terms of section 11(a).

However, it was made clear that royalty payments will not automatically be of a non-capital nature. The facts and circumstances of each case will have to be considered.

\section{Royalties Paid: Franchise Fees}

According to Erasmus (2007), it is important to look at the contractual relationship (franchise agreement) between the franchisor and franchisee to determine what rights are conferred to the franchisee. The agreement could provide for the payment of the following types of fees:

- $\quad$ an initial start-up fee payable for the exclusive use area. This fee would be of a capital nature as it creates an income-producing structure. It will not qualify for the section 11(f) deduction as it is not incurred for the right of use of any asset.

- $\quad$ an initial start-up fee payable for the right to use the intellectual property which belongs to the franchisor. This payment secures the right to use the intellectual property and is not for the actual use of the property. This part of the franchise fee could qualify for the section 11(f) deduction.

- $\quad$ on-going fees payable to maintain the use of the exclusive use area and the intellectual property (in the form of royalties). The deductibility of these royalty amounts was brought into doubt by ITC 1798, although the subsequent Supreme Court of Appeals decision provided more certainty.

The true intention of the parties needs to be determined. Account should be taken of the split between the initial fees (both for the right of use of the property as well as the fee for the exclusive use area) and the recurring monthly/annual fees and how this split was calculated. Erasmus (2007) advises that the franchise agreement must clearly and precisely describe what the fees and rights are that form the basis of the agreement.

If a taxpayer pays an amount to the owner of intellectual property for the cancellation of an agreement, that amount will not be a premium which can qualify for the section 11(f) deduction as it is not paid for the right of use of the property. The taxpayer may seek a deduction of such amount in terms of section 11(a) if all of the requirements are met.

\section{WITHHOLDING TAX ON ROYALTY PAYMENTS TO NON-RESIDENTS: SECTION 35}

A non-resident is liable for a final withholding tax of $12 \%$ of the gross amount of royalties paid to the nonresident. This withholding tax also applies when premiums are paid in respect of the right of use of intellectual property. The section is applicable in cases where certain intellectual property is used in South Africa; namely, patents, designs, trademarks, copyright, models, and motion picture films. It also applies to any scientific, technical, industrial, or commercial knowledge and assistance granted in respect of such items to be used in South Africa.

It is the responsibility of the person who incurs a liability to pay royalties or premiums to a non-resident to pay the withholding tax to the Commissioner. The provisions of section 35 are not applicable to amounts paid to a non-resident if such amounts are effectively connected with a permanent establishment of that non-resident in South 
Africa (proviso to section 35(1)). If the taxpayer has not withheld the tax from the payment to the non-resident and cannot recover it from the non-resident, it will be an expense for the taxpayer's own account.

\section{TAINTED INTELLECTUAL PROPERTY: SECTION 23I}

It may happen that amounts paid by a taxpayer in respect of intellectual property (for example royalties paid for the use of a patent) are not included in the income of the recipient; for example, if the recipient is a nonresident arguing that the royalties received are not from a source or deemed source in South Africa or if the royalties are paid to bodies which are exempt from tax. According to De Koker (2010), the aim of section 23I is to prevent avoidance of tax through the possible abuse of this situation by taxpayers who set up structures intended to make tax deductible payments to non-taxable persons.

The definition of "intellectual property" in section 23I(1) refers to patents, designs, trademarks, copyright and property of a similar nature, as well as to knowledge connected to the use of such items.

This section prohibits the deduction by a taxpayer of expenditure incurred for the use of (in terms of section $11(a)$ ), right of use or permission to use (in terms of section 11(f)), tainted intellectual property to the extent that the amount of the expenditure does not constitute income received by or accrued to any other person or to the extent that the amount of expenditure does not constitute a proportional amount of net income of a controlled foreign company which is included in the income of any resident of South Africa in terms of section 9D (section 23I(2)(a)). The section also disallows the deduction of expenditure if the amount of such expenditure is determined directly or indirectly with reference to expenditure incurred for the use, right of use, or permission to use tainted intellectual property to the extent that the amount is not included in another person's income as indicated (section 23I $(2)(b)$ ).

\section{"[T]ainted intellectual property" means intellectual property:}

- which was the property of the end user or of a taxable person that is or was a connected person, as defined in section $31(1 \mathrm{~A})$, in relation to the end user

- $\quad$ which is the property of a taxable person

- of which a material part was used by a taxable person in carrying on a business while that property was the property of a taxable person and the end user of that property acquired that business or a material part thereof as a going concern

- $\quad$ which was discovered, devised, developed, created, or produced by the end user of that property or by a taxable person that is a connected person, as defined in section $31(1 \mathrm{~A})$, in relation to the end user, if that end user, together with any taxable person that is a connected person in relation to that end user, holds at least 20 per cent of the participation rights, as defined in section 9D, in a person by or to whom an amount is received or accrues

$\circ \quad$ by virtue of the grant of use, right of use, or permission to use that property

- where that receipt, accrual, or amount is determined directly or indirectly with reference to expenditure incurred for the use, right of use, or permission to use that property(section 23I(1))

Certain persons - for example, non-residents and the government - are excluded from the definition of "taxable person".

"End user" means a taxable person or a person with a permanent establishment within the Republic of South Africa who uses intellectual property or any corresponding invention during a year of assessment to derive income, other than a person who derives income mainly by virtue of the grant of use, right of use, or permission to use intellectual property or any corresponding invention (section 23I(1)).

Section 23I does not apply to expenditure incurred for the acquisition of intellectual property, which would still be deductible in terms of section $11(\mathrm{gC})$, regardless of whether the requirements of section 23I are met. Section $23 \mathrm{I}$ also does not apply to deductions in respect of trading stock (section 23I(2)). 
It could happen that royalties paid to a non-resident in respect of tainted intellectual property results in a liability to withhold the $12 \%$ withholding tax stipulated by section 35 . If the taxpayer has withheld the $12 \%$ withholding tax in respect of royalties paid on such tainted intellectual property, the taxpayer will be allowed to deduct one-third of the royalty or premium payment (provided the requirements of section 11 $(a)$ or 11(f) are met). In other words, there will not be a complete prohibition of the deduction.

Some double tax agreements reduce the royalty withholding tax rate to zero percent, $5 \%$ or $10 \%$, depending on the tax treaty partner. If the rate of the withholding tax is reduced to less than $10 \%$ in terms of a double tax agreement, no deduction will be allowed (section 23I(3)).

\section{NO DOUBLE DEDUCTIONS ALLOWED - SECTION 23B}

Should an amount that was incurred by a taxpayer possibly qualify for deduction in terms of more than one section of the Act, section 23B restricts the deduction of that amount to a single deduction. This does not apply if a specific deduction section requires that, for an amount to be deductible under that section, the amount must be deducted in terms of another section of the Act. In such a case, both sections will be applicable to the amount.

There can also be no section 11(a) deduction in respect of any expenditure or loss of a type for which a deduction or allowance may be granted under any other provision of the Act. This means that should the taxpayer incur an expense in respect of intellectual property and that amount is of a type which may qualify for a specific deduction (e.g. the purchase of a patent), the requirements of the specific deduction section (section $11(\mathrm{gC})$ in such a case) have to be applied. Should the requirements for deduction of the amount not be met, the taxpayer may not then seek to deduct the amount in terms of the general deduction formula.

If the deduction of an amount that qualifies for a deduction in terms of a specific section is limited by that section (e.g., only $50 \%$ of the amount may be deducted), the taxpayer may not seek to deduct the balance of the amount (e.g., the other $50 \%$ of the amount) in terms of the general deduction formula (section $23 \mathrm{~B}(3)(a))$. If a specific deduction provides that an amount may only be allowed as a deduction or allowance in a subsequent year of assessment, the taxpayer may not deduct the amount in the current year of assessment in terms of the general deduction formula, even if all the requirements of section 11(a) are met (section 23B(3)(b)).

Therefore, section 23B provides certainty as to the order in which deductions are to be sought.

\section{CONCLUSION AND RECOMMENDATIONS}

The article provided a framework for determining the deductibility of intellectual property payments, as illustrated in Figure 1. It is recommended that the taxpayer consider all the factors pertaining to the various elements of this framework before a liability in respect of intellectual property expenditure is incurred.

If it is established that payments made for intellectual property (e.g., royalties paid) by a taxpayer do not qualify for a specific deduction, the taxpayer may need to seek a deduction in terms of section 11 $(a)$. The main problem is whether such payments are of a capital or non-capital nature. As none of the above-mentioned factors are conclusive on their own, the case law has indicated that they must all be taken into account in the context of the rights and privileges enjoyed by the taxpayer.

In cases where the payments secure an enduring benefit for the taxpayer and subsequently relate to the income-generating structure of the taxpayer (usually initial, once-off payments), they will be considered to be of a capital nature and not deductible. If they are of a recurring nature and merely relate to the use of the intellectual property while no transfer of ownership takes place, they could be regarded as of a non-capital nature and deductible. 


\section{AUTHOR INFORMATION}

Rudi Oosthuizen, M.Com. Currently he is a senior lecturer at the Department of Taxation, University of Pretoria, South Africa. He holds a bachelor's degree in accounting and a master's degree in taxation from the University of Pretoria. E-mail: rudi.oosthuizen@up.ac.za

\section{REFERENCES}

1. De Koker, A. (2010). Silke on South African Income Tax. Durban: LexisNexis Butterworths.

2. Du Plessis, E. (2006). Annual royalty payments held to be non-deductible, p. 51.

3. Erasmus, D. (2007). Royalties (franchise fees) and their deductibility. Paper presented at the FASA Tax Seminar, Cape Town, March 2007. [Online] Available

from:http://www.fasa.co.za/documents/Royalties_DanielErasmus.pdf [Accessed: 2010-08-25], pp. 5-14

4. Keyser, N. \& Mostert, L. (2009). Valuations not required to claim trademark allowances. The Taxpayer. September 2009, p. 168.

5. $\quad$ SARS 2007. Explanatory memorandum on the Revenue Laws Amendment Bill, p. 22.

6. SARS 2009. Interpretation Note no. 50, Income Tax: Deduction for scientific or technological research and development, pp. 6-34

\section{ACTS}

7. Income Tax Act, No. 58 of 1962.

8. Trademarks Act, No. 194 of 1993.

\section{CASE LAW}

9. BP Southern Africa (Pty) Ltd v The Commissioner for SARS, 2007 SCA 7 (RSA)(69 SATC 79).

10. British Insulated and Helsby Cables Ltd v Atherton, 1926 AC 205 All ER 623 (10 TC 155).

11. CIR $v$ African Oxygen Ltd, 1963 (1) SA 681(A) (25 SATC 67).

12. CIR v Butcher Bros (Pty) Ltd, 1945 AD 301 (13 SATC 21).

13. CIR v Genn \& Co (Pty) Ltd, 1955 (3) SA 293 (A)(20 SATC 13).

14. C:SARS v Kajadas Cosmetics (Pty) Ltd, 2002 (4) SA 709 (T) (64 SATC 200).

15. C:SARS v SA Silicone Products (Pty) Ltd, 20042 All SA 1 (SCA) (66 SATC 131 (SCA)).

16. Hallstrom Pty Ltd $v$ FCT (1946) 3 AITR 436 (72 CLR 634).

17. ITC 1224, (37 SATC 30).

18. ITC 1726, (64 SATC 236).

19. ITC 1798, (68 SATC 9).

20. ITC 1838, (72 SATC 6).

21. New State Areas Ltd v CIR, 1946 AD 610 (14 SATC 155).

22. Vallambrosa Rubber Co v Farmer, 1910 (5 TC 529). 